\title{
Resistance to EU integration? Norm collision in the coordination of development aid.
}

Johanne Døhlie Saltnes, Researcher, ARENA Centre for European Studies, University of Oslo. J.d.saltnes@arena.uio.no

\begin{abstract}
This article contributes to the contemporary foreign policy debate about how norms influence policymakers' behaviour. Hypotheses of norm-driven action are frequently dismissed when norms are inconsistently followed. However, values may collide, which might provide an explanation for such apparent inconsistencies. Drawing on recent constructivist literature on the contestation of norms, I discuss why integration in EU development policy was resisted. I ask if resistance was due to the wish to maintain national control over policies or if the socalled like-minded countries' resistance was due to a conflict of normative concerns regarding how to best achieve coordination. The study contributes by developing an empirically relevant hypothesis of norm collision which lends itself well for theoretical generalisation. In addition, the article provides new empirical knowledge about EU development policy by identifying the tension between securing country ownership and donor involvement as a crucial factor contributing to resistance to EU integration.
\end{abstract}

Keywords: norm collision; EU development policy; like-minded countries; constructivism; donor coordination 


\section{Introduction}

European Union $(\mathrm{EU})^{1}$ development policy holds an ambiguous status as exclusively subjected neither to supranational nor to intergovernmental procedures. Member states and EU institutions develop legislation alongside each other; however, they are required to avoid duplication and to avoid promoting contradictory objectives (Orbie and Lightfoot 2017). In the literature on EU development policy, it is generally assumed that resistance towards common EU policy initiatives results from a desire for maintaining national control over policies (Carbone 2008, 2013a, 2013b, 2017; Horký 2012; Orbie and Lightfoot 2017). ${ }^{2}$ In this article I question this assumption by analysing negotiations leading to a common EU policy on coordinating donors' choice of aid recipients (donor coordination). Drawing on insights from recent constructivist literature on the contestation of norms, I discuss if what could be perceived as resistance to integration was instead the result of a conflict of normative concerns regarding how donor coordination could best be achieved (Hofferberth and Weber 2015; Krook and True 2012; Puetter and Wiener 2007; Van Kersbergen and Verbeek 2007; Wiener 2008). I add to the literature regarding resistance to EU integration, as well as to the broader international relations (IR) debate on the influence of norms on policymakers' behaviour, by developing an empirically relevant hypothesis of norm collision that lends itself well for theoretical generalisation.

I develop this argument in a case study of EU foreign aid. More specifically, I look at the negotiations of an EU initiative which seeks to enhance coordination among the member states donor practices. The initiative is known as 'The code of conduct on complementarity

\footnotetext{
${ }^{1}$ In line with Hill and Smith $(2005,8)$ I define the EU as 'a set of international institutions and arrangements within which the interests and preferences of member states and other actors can be coordinated for international purposes'.

${ }^{2}$ See two special issues which discuss resistance to integration in development (Bodenstein, Faust, and Furness 2017; Orbie and Carbone 2016) as well as the special issue on the Union's Policy Coherence for Development (Carbone 2008).
} 
and division of labour' (Council of Ministers 2007). When the Commission proposed a common policy on donor coordination, a group of EU member states, known as the likeminded $^{3}$ were reluctant. Their resistance is puzzling since the like-minded were principal proponents of donor coordination in international fora such as the United Nations (Elgström 2016; Elgström and Delputte 2015; Olsen 2013; Stokke 1989). I ask, why did the like-minded oppose an EU policy that aimed at achieving one of their central goals?

Many would argue that the like-minded's scepticism is an example of classic foreign policy behaviour. ${ }^{4}$ A recurrent phenomenon in international relations is that states say one thing but do another. Such situations of inconsistency between rhetoric and practice often result in accusations of hypocrisy. When norms are not followed consistently, the general trend in IR scholarship is to return to interest-based hypotheses assuming that actors seek to maximise utility. This dichotomization of interests and norms is especially visible in the literature on foreign aid where the image of an idealistic donor giving aid for altruistic reasons is juxtaposed with the image of a self-interested donor exploiting aid recipients for the purpose of its own economic benefit (Easterly 2006; Lumsdaine 1993; Stokke 1989). Whereas these two images are helpful starting points, we need more nuanced analytical conceptualisation to better grasp donors' decisions regarding foreign aid. The global debate on aid effectiveness is just one example of how there are different and sometimes contending normative principles in aid policies. Collision of norms can occur both on goals, i.e. aid effectiveness vs. gender

\footnotetext{
${ }^{3}$ The like-minded are Sweden, Denmark, Finland, the United Kingdom, Ireland, and the Netherlands. They are also known as the Nordic+ Group (including Norway and Canada). Scholars usually make a distinction between the like-minded and a group of southern member states (the founding members except the Netherlands and the new member states (ms)), whom I will refer to as the southern ms (Orbie and Lightfoot 2017). Some scholars use a three-fold distinction between the like-minded, the clubmed (southern ms, including France, and new ms) and the 'fence-sitters', that is, Belgium and Austria (sometimes Ireland). I use the distinction between the like-minded and the southern ms since that was the two main groupings during the negotiations of the EU's donor coordination initiative. See also Carbone (2007).

${ }^{4}$ Other common hypotheses for resistance to integration in the field of development is the existence of competing donor identities (Delputte and Orbie 2014) and a general resistance to more supranational legislation. See below for a discussion of existing hypotheses.
} 
equality and on means to achieve a goal, i.e. competing views on how the value-based goal aid effectiveness could be best achieved. Particularly evident in the realm of foreign aid is the tension between recipient country ownership and donor involvement. On the one hand, ownership implies that developing countries set their own strategies for poverty reduction which allows for a better targeting of resources and increased likelihood for sustainability and success. On the other, donor involvement is also considered important for accountability and to avoid corruption, especially in relation to recipients with weak institutions. Therefore, to understand donors' decisions within this increasingly complex area of international relations, and the role of norms within it, we need more nuanced analytical conceptions than the conventional images of self-interested or altruistic donors.

This article contributes to this endeavour by investigating to what extent the collision between the normative concerns for recipient ownership and donor involvement account for the likeminded's resistance to the EU's donor coordination policy. I bring the contemporary debate on norm contestation and collision to the area of foreign aid in general and to EU development policy in particular. I rely on theory which considers acting in accordance with a norm to be equally rational to acting in line with interests. Thereby, it is also possible to consider the possibility that actors may be faced with different and possibly colliding norms. The starting point is the observation that there may be competing views on how donor coordination could best be achieved. Arguably, we need to at least consider the theoretical possibility that member state scepticism towards a common policy may result from collision of normative concerns rather than from concerns for maintaining national control.

\section{Donor Coordination}

At the turn of the millennium, the need for a closer coordination of aid policies globally was imminent. The main problem was the transaction costs incurred by those at the receiving end. Recipients of foreign aid often managed incoming funds from more than 25 donors, all 
demanding different reporting procedures, control mechanisms and extensive meeting activity. Most donors were aware that lack of coordination among their individual aid policies caused various problems. However, it was the so-called like-minded countries, most of whom were also EU member states, that put the issue on the international agenda in the early 2000s. The like-minded pushed for coordination to be a central part of the 2005 Paris declaration on aid effectiveness, negotiated in the Organisation for Economic Co-operation and Development (OECD).

The EU had a comparative advantage in making coordination come about because of its institutional structure and experience with coordination of member state policies in a wide range of areas. Yet, the like-minded were sceptical about participating in the EU initiative (MS-1, -2, -3, -4, -5, -6, -7, -8, -9, COU-1, COM-1, -2, -3, -4, -5). Several scholars have identified a sceptical attitude by like-minded countries towards initiatives in the realm of development (Carbone 2007, 2013a; Delputte and Orbie 2014; Elgström and Delputte 2015). 'Their national positions to the proposals submitted to CODEV are predictable, with a special "aversion" to the adjective "joint". These countries "do not want the EU flag"; they "fear losing their freedom" and simply block the proposals' (Horký 2012, 65). However, the likeminded's sceptical attitude in the negotiations of the EU code of conduct has so far not been investigated. The policy was negotiated in the development working group in the Council, CODEV, in 2006 and spring 2007 and was adopted as Council Conclusions by the General Affairs and External Relations Council (GAERC) 15 May 2007.

\section{Analytical Approach}

The literature on foreign aid contains two standard explanations of why states resist integration. The first assumes that states want to maintain control over aid decisions because aid is linked to broader foreign policy goals. The second emphasises the existence of 'competing donor identities' and assumes that donors' self-understanding as globalists 
motivates them to cooperate only on an intergovernmental level such as through the UN. These standard explanations might prove relevant to understand the like-minded's resistance to the EU's donor coordination initiative and will be investigated below. However, I argue that it is also necessary to investigate a third alternative which relies on the assumption that states may be reluctant to participate in common policies because of competing views on how to reach aid effectiveness. Such situations of norm collision are increasingly pointed to empirically and might provide a fruitful hypothesis for investigating the like-minded's resistance to the code of conduct (Elgström and Pilegaard 2008; Del Biondo 2015).

The standard assumption in the foreign aid literature is that donor decisions are dominated by 'domestic interests'. Two types of such interests are discernible: First, donors are expected to be concerned with retaining control over who receives aid because aid relations can be used to secure commercial or security interests by maintaining relations with strategically important recipients (Alesina and Dollar 2000; Bigsten and Tengström 2015; Carbone 2008, 2013a, 2013b, 2017; Fuchs, Nunnenkamp, and Öhler 2015). This is however not a relevant objection to the EU's donor coordination initiative, because the initiative does not propose that member states should phase out large aid programmes or withdraw from countries which they consider to be important partners. The second type of domestic interest often assumed to be at play is visibility. Visibility could be related to aid bureaucrats protecting their turf because they are afraid of losing power (Carbone 2013a; Easterly 2002) or making the contributions of aid policy visible to constituencies and parliamentarians at home (Bourguignon and Platteau 2015; Carbone 2013b; Furness and Gänzle 2017; Versluys 2008). Such concerns are often connected to aid effectiveness as a goal. Donors want to be present in recipient countries that 'perform well' because they need to report to domestic institutions about successful project implementation (Aldaroso, Nunnenkamp, and Thiele 2010). Visibility might be especially important for the like-minded countries since they are among the most generous aid donors in 
the world and were the first countries to reach the UN target of spending $0.7 \%$ of annual budgets on aid. According to this line of thinking, donors consider it important to retain control over who receives aid, to be able to point out visibility and to control putative reallocations of funds. Accordingly, giving up the right to decide who receives aid does not serve their interests. Such an explanation resonates with rationalist theory, where the central expectation is that actors are instrumentally rational and act to maximize expected utility. In accordance with this perspective, the following hypothesis was devised:

H1: The like-minded were sceptical to the code of conduct because giving up national control over deciding which recipients should receive aid would harm their ability to point out visibility to domestic actors.

Another common explanation that may be relevant for understanding this case relates to the existence of 'competing donor identities' (Delputte and Orbie 2014; Delputte and Söderbaum 2012; Elgström and Delputte 2015; Smith 2013). It has been suggested that the like-minded first and foremost see themselves as globalists: 'More intense EU coordination conflicts with their identity, which corresponds more with supporting the principle of multilateralism than being an EU donor' (Delputte and Orbie 2014, 686). Being part of the like-minded donor group could thus be an inhibiting factor for participating in common EU initiatives. ${ }^{5}$

To account for identity conflicts, scholars often draw on role theory (Holsti 1970). Roles can be defined as 'patterns of expected or appropriate behaviour' (Elgström and Smith 2006, 5). Decisions are made as a result of actors reflecting on who they are and what is expected of them, given their identity. Whereas in $\mathrm{H} 1$ decision-makers would act according to a logic of consequences, this second hypothesis conceives of actors adhering to a logic of

\footnotetext{
${ }^{5}$ Similar hypotheses assuming that countries resist EU integration because they consider their own policy to be 'better' or because of a principled concern for national sovereignty could also be captured by such an identity conception.
} 
appropriateness. 'Actors seek to fulfil the obligations encapsulated in a role, an identity, a membership in a political community or group, and the ethos, practices, and expectations of its institutions' (March and Olsen 2009). In accordance with this perspective, the following hypothesis was devised:

H2: The like-minded were sceptical to the code of conduct because their self-understanding as like-minded donors urged them to seek global solutions rather than a European solution.

In addition, I propose a third alternative which assumes that the like-minded resisted the code of conduct because of a conflict of normative concerns, namely that the like-minded and the southern ms had competing views of how coordination should be organised. The hypothesis reflects the broader phenomenon of norm collision: actors do not always agree on what is 'the right thing to do'. The so-called second-generation constructivists have recently focused on the dynamic nature of norms, emphasising the possibility of competing interpretations of norms (Hofferberth and Weber 2015; Puetter and Wiener 2007; Van Kersbergen and Verbeek 2007; Wiener 2008). They observe that international norms are often vague by design and their content can be filled in many ways. Instead of conceiving of norms as fixed principles, as first generation of constructivist scholars, second-generation constructivists view norms as 'works-in-progress' (Krook and True 2012, 104).

Second-generation constructivists have taken the literature on the influence of norms on policymaking an important step forward by observing how norms are contested and change over time. Adding to this literature, I propose to engage with norm contestation by anchoring the collision of normative concerns to a concept of communicative rationality (Habermas 1993). Rational behaviour is then linked to providing justifications for one's actions. The communicative perspective emphasises the 'cognitive core' of normative questions - 'the right thing to do is what can be argumentatively justified' (Eriksen and Weigård 2003, 155). It 
is through the process of giving and taking of reasons that actors can assess the validity of normative claims and decide if they want to act accordingly (Eriksen and Weigård 2003; Risse 2000). In accordance with this concept, acting out of a normative concern is considered to be equally rational to acting according to interests.

I rely on the communicative perspective to theoretically anchor the phenomenon that secondgeneration constructivists observe. Then, relying on this concept, we may account for the possibility of actors considering different normative concerns as well as actors disagreeing on what is 'appropriate' action. The added value is the possibility of discriminating between different normative concerns. Hence, we may also account for situations where actors oppose a certain policy although they agree with its overall goal. The reason for objection may be linked to disagreements on what is the best way to achieve this goal (aid effectiveness).

A tension between the concern for recipient ownership and donor involvement, both of which (from different perspectives) can be argued to enhance aid effectiveness, is expected to be the most important normative conflict for spelling out a common EU policy on donor coordination. This is because the like-minded countries were particularly concerned with promoting ownership when the code of conduct was negotiated. Ownership entails that recipients set their own development strategies and places responsibility and decisions in the recipients' hands. It may lead to situations where recipients take decisions that are at odds with donors' preferences or what they consider to be the right thing to do, hence also reducing donors' influence over the funds in question. Emphasising ownership reflects an awareness of the need to recognise difference - that there is not one standard solution suitable for all actors. It underlines that we cannot know what is the best thing to do unless we hear the viewpoints of all affected parties (Eriksen 2016). Emphasising ownership in donor coordination would entail giving recipients due hearing in the coordination process. Conversely, one could argue that it is possible to find a neutral solution to donor coordination. To find such an un-biased 
solution, that in principle may be seen as justifiable from the perspectives of all, it is necessary to involve authoritative institutions that interpret and enforce commonly agreed norms, hence including an element of donor involvement. Such an interpretation would favour the viewpoint that there is one common way to conduct coordination and that common EU institutions would be the adequate agents to implement coordination. Then, drawing on a communicative perspective, the following hypothesis was devised:

H3: The like-minded were reluctant towards the code of conduct because they wanted recipient countries to participate in coordination decisions, whereas the southern ms wanted coordination to be a task for the Commission and the member states only.

\section{Method and Data}

In this article, I seek to explain why the like-minded were reluctant to agree to a common European policy on donor coordination even though they advocated for coordination in principle. To explain the reasons for this reluctance, I analyse the like-minded's position in the negotiations of the EU's common policy on donor coordination - the code of conduct (Council of Ministers 2007). The method applied is to systematically collect and interpret reasons presented by the like-minded and southern ms during negotiations (Sjursen 2002). The choice of method follows from the theoretical framework. Interpreting arguments allows for evaluating through empirical investigation the relative importance of pragmatic considerations relating to interests and different normative considerations. The analysis belongs to the interpretative tradition where the aim is to discover the reasons behind a position from the actor's viewpoint (Weber 1978). To substantiate the three hypotheses, I will look for the following arguments: H1 would be indicated by concerns among like-minded representatives for maintaining the right to decide where and when to exit from recipient states and sectors to be able to point out to their constituencies the positive consequences of providing aid. In particular, it is expected that representatives want to maintain relations with 
'good performers', to show constituents that aid is used 'successfully'. H2 would be indicated by like-minded representatives voicing preference for a global solution and making clear that an EU solution is not a preferred alternative. Lastly, $\mathrm{H} 3$ would be indicated by like-minded representatives emphasising the need to secure a role for recipient countries in the coordination process, because they are considered to be legitimate participants in the process. The study belongs to what Yin $(2014,51-52)$ labels 'single-case design', using the rationale of being a 'common case' of an intergovernmentally agreed upon EU development initiative that seeks to enhance aid effectiveness. The analysis draws on 15 semi-structured interviews with representatives from EU and member state institutions, official documents from the likeminded member states, and relevant secondary literature. To control for consistency, the triangulation of sources has been important. Official documents were obtained through freedom of information requests (FOI) to the United Kingdom and Denmark (chosen as representatives for the like-minded group because they were identified as the most sceptical countries by interviewees), asking for all existing information concerning negotiations of the code of conduct. ${ }^{6}$ The FOI requests resulted in the provision of archived notes, letters, emails, position papers, and speaking notes from bureaucrats as well as from politicians and ministers involved in negotiations of the code of conduct. In addition, I conducted systematic searches in online resources of all the like-minded countries. Interviewees were representatives from the like-minded and southern ms, the Council secretariat and the Commission that were involved in negotiations of the code of conduct. ${ }^{7}$ Due to concerns for anonymity, the national origin of these representatives is not revealed, which heightened the

\footnotetext{
${ }^{6} \mathrm{FOI}$ requests were conducted by e-mail to the UK's Department for International Development (DFID) 19.08.2016 (id: F2016-258) and Denmark's development cooperation programme (Danida) 22.09.2016 (id: 2016-39406/ 1541946).

${ }^{7}$ Interviewees were EU and member state representatives to CODEV in 2006 and 2007, which is the period when the code of conduct was negotiated as well as aid effectiveness staff from the capitals. Their institutional affiliation reflects the position they held when working with the code of conduct and not the position they held when interviewed. See a list of interviewees at the end of the article.
} 
likelihood representatives would give meaningful arguments for their positions. Interviews with representatives not belonging to the like-minded group were used to check for consistency.

\section{Analysis}

Then, how sceptical were the like-minded countries to the code of conduct and how can we account for this reluctance to a common European policy on donor coordination?

\section{A Question of National Visibility?}

One of the central points in the Commission's proposal for a code of conduct was geographical specialisation:

Guiding principle 5 - Establish priority countries.

EU donors will reinforce their geographical focus, through a dialogue within the EU, taking into account the broader donor engagement (European Commission 2007).

There were too many donors present in some recipient countries (donor darlings), while other recipients were receiving little or no development cooperation (donor orphans). Coordinated geographical specialisation was supposed to be a remedy for both these problems. The idea was that all donors should engage in a process of reducing the number of recipients and restrict donor presence to a number of 'focus countries'. The selection of recipients should be made in consultation with other donors to ensure a reasonable distribution. Yet, the proposition of a principle of such cross-country complementarity was controversial. This is visible in the reformulation of the principle in the final document (Council of Ministers 2007):

The Council invites the member states and the Commission to conduct an EU dialogue about future engagement and on strategic planning concerning their geographic 
concentration and country priorities, while recognising that member states' decisions on this issue are sovereign national decisions.

All like-minded representatives voiced a particular reluctance to let the EU interfere with their choice of reducing the number of recipient countries (MS-1, -2, -5, -6, -7, -8, -9, COU-1). A typical example is the communication between the then Danish development minister, Ulla Tørnæs, and the EU presidency development minister from Germany, Heidemarie WieczorekZeul: 'I wish to stress clearly that we will not accept Council conclusions that tamper with the competence in relation to development assistance. Member states still have to decide on their choice of partner countries and sectors', read the speaking notes of Tørnæs from a meeting in February 2007 (FOI DK 2007b). Such opposition to giving up the right to decide on geographical specialisation was also visible in official documents of Sweden and the United Kingdom (FOI UK 2007b, 2007c; Utrikesdepartementet 2007). Yet, to tease out the reasons for like-minded resistance, it is necessary to identify the justifications for their position.

Most like-minded interviewees backed up their position with vague statements of concerns for domestic interests, a typical example being:

We found out that these decisions on country selection of partner countries were so political and so unilateral and had so much to do with domestic interests that it was basically impossible to get this cross-country division of labour coordinated (MS-7).

References to the process's being 'political' were frequent. When asking for what was meant by political, most interviewees emphasised that it was important to secure democratic anchoring of development assistance in national parliaments. One example of such a statement is, 'Political support is not guaranteed. It implies that the government has to make a case for what they are doing and why they are doing it' (MS-2). This statement shows how the concern for visibility was not connected to pointing out economic gain to satisfy 
constituents. Rather, it arose from a need to democratically anchor the existence of a substantial aid policy and provide accountability for this part of the budget. This observation was also found across all documents obtained through the FOI requests. For instance, in a letter Tørnæs writes to Wieczorek-Zeul:

The choice of partner countries and sectors is a political issue in all donor countries and often involves Parliaments (...) a mechanistic model for the division of labour is not realistic and would risk sending signals that could weaken domestic backing for development assistance (FOI DK 2007e).

So far, the analysis suggests that like-minded representatives were concerned with satisfying domestic actors. Yet the evidence shows that this is not a clear-cut case of visibility as derived by H1. The like-minded were not reluctant because keeping control over who received aid best served their interest; rather, their scepticism grew out of a concern for securing with domestic institutions a legitimate and democratic anchoring of development cooperation. Keeping a certain number of donor-recipient relationships was important to justify to the parliament and the constituents that a large aid budget was legitimate. However, this evidence relates only to the like-minded's scepticism towards the principle of geographical specialisation. Several other issues remained contested, inter alia, the number of sectors each donor should be allowed to be involved in in each recipient country, and the role of recipient states in decision-making on coordination. Can the like-minded's self-understanding as globalists account for their resistance?

\section{Like-minded Globalists?}

Ever since Stokke's (1989) characterisation of the like-minded countries as 'humane internationalists', the preference of these countries to seek solutions to global challenges through global institutions has been emphasised (Delputte and Orbie 2014; Elgström and 
Delputte 2015). The starting point for like-minded cooperation was the Utstein group formed by the female development ministers Clare Short (the United Kingdom), Evelina Herfkens (the Netherlands), Heidemarie Wieczorek-Zeul (Germany), and Hilde Johnsen (Norway) in 1998. These ministers had worked in or closely with global development institutions such as the World Bank and the UN. The Utstein group laid ground for what became a system of frequent and informal coordination among like-minded donors on issues of aid. Germany reduced their cooperation with the like-minded when Angela Merkel took office in 2005, whereas other like-minded countries joined. The existence of a like-minded identity in development policy has been widely described in the literature and has been referred to as an inhibiting factor for EU integration. According to Delputte and Söderbaum (2012, 54):

This explains why most EU member states are not overly enthusiastic about a common EU development policy: It simply competes with their identity as donors in a way which other forms of donor coordination, such as the Paris Agenda and lead donor do not.

Can this self-understanding as globalists account for the like-minded's resistance to the code of conduct?

There is some evidence suggesting that the like-minded's self-understanding as globalists was important (MS-1), one example being: 'our minister, she came from the World Bank, so she was more oriented towards the multilateral development banks and she had no interest in the EU' (MS-7). The like-minded's self-understanding as globalists was also confirmed by representatives from the Commission and by the southern ms emphasising that this was a recurrent argument in CODEV (COM-4, -5; MS-3). Yet in addition to these and similar statements of a like-minded tendency to look to the UN and the World Bank, a strong preference for finding a European solution was also identified: 
The way we pursue our policy is with the like-minded, similar to other countries, so for us we are not totally happy without the EU as a whole (...) it is not that we want to stay away from a European approach (MS-2).

The government is positive towards the proposal for a code of conduct (...) the EU could be a driving force in reaching coordination (...) But, the EU must always act as part of a broader donor community (Utrikesdepartementet 2007) (my translation).

Although there is evidence of a like-minded identity, the like-minded's self-understanding as globalists cannot help us understand their reluctance to the code of conduct in particular. There was an equal number of statements by like-minded representatives reflecting their will to find a European solution. This evidence suggests that the like-minded's resistance to the code of conduct was not principled as derived by $\mathrm{H} 2$.

Incidentally, I found evidence of an identity also among the southern ms. Most southern ms representatives voiced concern for making donor coordination a specific EU addition to the aid-effectiveness agenda. Southern ms representatives therefore opposed the like-minded's position of keeping the code of conduct open to other donors. For the southern ms, the code of conduct should be an exclusive EU policy. Enhancing the EU's status as an actor in development was a clear motivation for their position (MS-5, -6, -8, -9). In addition, an EU code of conduct would open the possibility of leading by example (MS-5, -6). Eventually, the southern ms agreed to keep the code open to other donors because they recognised that a generic code could still give the EU a leading role internationally:

We came to the conclusion that we could have this EU-leading tradition in division of labour $(\ldots)$ even if we opened it to other donors, we were still the most important development actor in the field (MS-6). 
Thus, although there is evidence of identity logics, these cannot help us understand the likeminded's hesitant attitude towards the code. Can the collision of norms help us account for the like-minded's resistance?

\section{A Collision of Normative Concerns?}

There is substantial evidence of a collision between the concerns for country ownership and donor involvement One of the issues where this tension was visible was the like-minded's disagreement with the southern ms on limiting donor presence to three sectors in each recipient country. Like-minded interviewees emphasised the need for recipients to participate in the decision of sector concentration. They argued that if donors were to reduce the number of countries they were to be involved in, it might be necessary to maintain support for a wide range of sectors in some important partner countries (MS-1, -2, -7). This argument was also found in official documents, especially in the United Kingdom. In a debate in the House of Commons, Gareth Thomas explains the UK's position:

We have sought amendments to the document to recognise the situation that we face as a donor: in some of our key countries we work in nine different sectors. Clearly, some developing countries' governments will want donors who work in many sectors to maintain their spread in those sectors (House of Commons 2007).

The issue of not restricting donor presence to three sectors proved to be so important to the United Kingdom that they managed to have a footnote added to the final version of the code of conduct:

In limited cases, where donors face a significant reduction in sector coverage, this target may be increased to engage in more than three sectors, taking full account of partner countries' views, neglected issues of particular importance and a realistic 
timeframe to support any change in their country programmes (Council of Ministers 2007).

The UK's negotiating representative reported to be satisfied with the outcome: 'This is far more than we could have hoped for given the previous positions adopted by other member states and the Commission (...) We have avoided being isolated in rejecting an aid effectiveness commitment' (FOI UK 2007a). This statement shows the duality of the UK position. They did not oppose the overall goal of the policy but disagreed with parts of the content to the extent that it made them reluctant to participate. A strict rule of a maximum of three sectors for each donor would not necessarily be considered appropriate either by the donor or by the recipient. Moreover, the United Kingdom stands out as the most sceptical member state within the like-minded group. This finding suggests that the like-minded's position was not always as united as often assumed in studies relying on 'donor identities' (Elgström and Delputte 2015).

In addition, the concern for including recipients in decisions on coordination was a general concern visible across all official documents of the like-minded (FOI DK 2007a, 2007b, 2007c, 2007d, 2007e; FOI UK 2007a, 2007b, 2007c; Utrikesdepartementet 2007).

The donors cannot simply distribute countries and sectors without involvement of the recipient countries $[\ldots]$ revealing the preferences of the recipient countries and identifying the comparative advantage of the donors will be crucial elements in the efforts to secure a better division of labour (FOI DK 2007a).

... emphasises the importance of the role of developing partner governments in determining the framework for donor support and identifying preferred partners and calls for building on current in-country initiatives and is open to all donors (FOI UK 2007c). 
The emphasis on including all affected parties in the decision-making process underlines the interpretation of donor coordination in line with the ownership principle. To find the best possible solution, it was necessary to give all affected parties due hearing. The like-minded interviewees also accentuated this position: 'It is very important that it is the government [recipient] that needs to establish the agenda. And then we should make sure that we are complementing their efforts' (MS-1). Similarly, another like-minded representative said:

The first principle is the primary leadership and ownership, in-country division of labour should be with the partner-country government (...) we support the idea of presenting the EU as one, as a big player, but not led by the Commission only, led with the partners as well (MS-9).

For the southern ms, on the other hand, ownership was not emphasised. Rather, they wanted a strong Commission to ensure that coordination would be implemented efficiently. For the southern ms, the most important concern was to achieve coordination to change the current situation. Including recipients could lead to increased coordination problems (MS-3, -5, -6, -9; COM-2). Some interviewees were even sceptical of giving recipients a larger role: 'Sometimes governments like to play with donors, and this should be avoided because of things like corruption - so donor coordination is very important' (MS-8). Nor can one automatically assume that donor coordination was what (all) recipients preferred. Carbone (2010, 2013a), has argued that increased coordination leaves the recipient with less space for negotiations. In sum, the southern ms emphasised donor involvement over recipient ownership. A strong Commission was preferred over giving recipients a say in the coordination process.

In sum, the analysis shows that in line with H3, the like-minded's opposition to the Commission proposal on donor coordination resulted from a conflict of normative concerns 
regarding how donor coordination could best be achieved. The collision between country ownership and donor involvement each of which is argued to enhance aid effectiveness (from different perspectives), has not previously been identified. The like-minded's position reflects an awareness of the need to recognize difference and autonomy. The proposal of one standard solution (i.e., limiting donor involvement to three sectors) was not considered to be suitable in all instances. For the southern ms, on the other hand, a strong Commission was crucial to ensure that member states really worked better together. This position reflects the viewpoint that it is possible to find one neutral and un-biased solution to donor coordination and that authoritative institutions can take the role of interpreting and enforcing commonly agreed norms that in principle may be seen as justifiable from the perspectives of all.

\section{Conclusion}

In this article I have explained why the so-called like-minded countries were sceptical to a common European policy on donor coordination despite this being an important goal for these countries. By interpreting the reasons the like-minded presented for their actions, I find that a collision between the concern for country ownership and the concern for donor involvement is the dominant factor that accounts for the like-minded's resistance. The article adds to the literature on EU development policy in several ways. First, the findings show that the tension between country ownership and donor involvement was a decisive factor of the like-minded's scepticism towards EU donor coordination. Whereas the standard assumptions in the literature, respectively emphasising domestic interests and competing donor identities, were relevant, it was necessary to add a third hypothesis reflecting a collision of normative concerns to fully account for the like-minded's scepticism towards the code of conduct. Thus, what is often labelled the Eurosceptic attitude of the like-minded was not a principled scepticism towards 'more Europe', but rather a concern for making sure that recipients were involved in the coordination process. Second, the article supports the thesis of so-called like- 
mindisation of EU development policy since the final agreement mirrored the like-minded's position (Elgström 2016; Elgström and Delputte 2015; Olsen 2013). Finally, the findings contradict the interpretation of policy incoherence as a result of conflicts of interests (Carbone 2008). I suggest that that incoherence also may result from a conflict of norms.

While the case investigated in this article dates back to 2007 the relevance of the norm collision hypothesis might be equally relevant for understanding more recent EU development initiatives. The development policies of most donors have now been redefined in accordance with the UN Sustainable Development Agenda (2015) which has put the goal of protecting the planet on an equal footing with eradicating poverty. Attending to concerns for both the people and the planet might foster competing normative viewpoints on what an effective development policy post 2015 should entail. The identification of norm collision in the EU's development policy mirrors insights by the so-called second-generation constructivists on norm contestation and the possibility of conflicting interpretation of norms (Hofferberth and Weber 2015; Krook and True 2012; Puetter and Wiener 2007; Van Kersbergen and Verbeek 2007; Wiener 2008). I have suggested that we get a more nuanced understanding of the likeminded's scepticism by applying an approach that conceives of the choice to follow a normative concern as rational. I have combined the assumption of norms having a rational core with an empirical focus on the decision-making process at the EU level, resulting in novel insights. While the second-generation constructivists often emphasise the domestic nature of norm contestation, I find that member state positions are also challenged, discussed and sometimes altered at the EU level. Thereby, the findings support the existence of a certain level of (EU) agency in the realm of development (Smith 2016). Whereas the EU is not necessarily found to be a 'norm-maker' in donor coordination, it proved to be a relevant actor for discussing the different and sometimes competing normative concerns the EU is grappling with in its development policy (Orbie 2012). 
Moreover, the analysis contributes to the debate regarding norms in international relations and the question of to what extent norms can shape and determine action in foreign policy. Hypotheses of norm-driven action are often dismissed when norms are not followed consistently. The general trend in IR scholarship is then to return to interest-based hypotheses, and to use the gap between rhetoric and practice as evidence of hypocrisy. This trend is especially visible in the literature on development aid, where actors are juxtaposed as either altruistic idealists or self-interested realists using aid as a means to satisfy economic or security concerns (Easterly 2006; Lumsdaine 1993; Stokke 1989). This duality fails to adequately capture actions that are conducted in accordance with norms. While the latter does not assign any role to normative considerations, the former does not provide an account of why norms are followed, other than that it is 'good behaviour'. Drawing on the concept of communicative rationality, I have suggested to complement existing approaches with one that allows for actors to evaluate different, possibly colliding, normative concerns. The lack of norm-consistent behaviour is not necessarily accounted for by self-interested reasons but might be explained by disagreements regarding what is the best thing to do. Given that the EU has committed to follow a range of different values in its external policies, such an approach might also be relevant for studies of the EU's foreign policy more generally.

\section{Acknowledgments}

An earlier version of this paper was presented at the GLOBUS workshop on trade, development and global justice 30 May 2017 in Johannesburg and the EISA Conference 30 September 2017. I thank the participants in these workshops for their comments. Also, I would like to thank two anonymous reviewers for their constructive feedback and extend a particular thanks to Helene Sjursen for excellent advice and comments on several drafts of this article. This article is part of the EuroDiv project at ARENA, a research project financed by the Research Council of Norway's research initiative ‘Europe in Transition’ (EUROPA). 


\section{References}

Aldaroso, I., P. Nunnenkamp, and R. Thiele. 2010. 'Less Aid Proliferation and More Donor Coordination? The Wide Gap between Words and Deeds.' Journal of International Development 22(7): 920-940.

Alesina, A. and D. Dollar. 2000. 'Who Gives Foreign Aid to Whom and Why?' Journal of Economic Growth 5: 33-63.

Bigsten, A. and S. Tengstam. 2015. 'International Coordination and the Effectiveness of Aid.' World Development 69(1): 75-85.

Bodenstein, T., J. Faust, and M. Furness. 2017. 'European Union Development Policy: Collective Action in Times of Global Transformation and Domestic Crisis.' Development Policy Review 35(4): 441-453.

Bourguignon, F. and J. P. Platteau. 2015. 'The Hard Challenge of Aid Coordination.' World Development 69: 86-97.

Carbone, M. 2007. The European Union and International Development: The Politics of Foreign Aid. London and New York: Routledge.

Carbone, M. 2008. 'Mission Impossible: The European Union and Policy Coherence for Development.' Journal of European Integration 30(3): 323-342.

Carbone, M. 2010. 'The European Union, Good Governance and Aid Co-ordination.' Third World Quarterly 31(1): 13-29.

Carbone, M. 2013a. 'Between EU Actorness and Aid Effectiveness: The Logics of EU Aid to Sub-Saharan Africa.' International Relations 27(3): 341-355.

Carbone, M. 2013b. 'Foreign Aid, Donor Coordination and Recipient Ownership in EUAfrica Relations.' In The European Union in Africa: Incoherent Policies, Asymmetrical Partnership, Declining Relevance? edited by M. Carbone. Manchester: Manchester University Press.

Carbone, M. 2017. 'Make Europe Happen on the Ground? Enabling and Constraining Factors for European Union Aid Coordination in Africa.' Development Policy Review 35(4): 531-548.

Del Biondo, K. 2015. 'Norms or Interests? Explaining Instrumental Variation in EU Democracy Promotion in Africa.' Journal of Common Market Studies 53(2): 237-254.

Delputte, S. and J. Orbie. 2014. 'The EU and Donor Coordination on the Ground: Perspectives from Tanzania and Zambia.' European Journal of Development Research 26: 676-691.

Delputte, S. and F. Söderbaum. 2012. 'European Aid Coordination in Africa: Is the Commission Calling the Tune?' In The European Union and Global Development: An 'Enlightened Superpower' in the Making? edited by S. Gänzle, S. Grimm, and D. Makhan. Basingstoke: Palgrave Macmillan.

Easterly, W. 2002. 'The Cartel of Good Intentions: The Problem of Bureaucracy in Foreign Aid.' The Journal of Policy Reform 5(4): 223-250.

Easterly, W. 2006. The white man's burden: Why the West's efforts to aid the rest has done so much ill and so little good. New York: Penguin Press.

Elgström, O. 2016. 'Norm Advocacy Networks: Nordic and Like-Minded Countries in EU Gender and Development Policy.' Cooperation and Conflict 52(2): 224-240

Elgström, O. and S. Delputte. 2015. 'An End to Nordic Exceptionalism? Europeanisation and Nordic Development Policies.' European Politics and Society 17(1): 28-41.

Elgström, O. and J. Pilegaard. 2008. 'Imposed Coherence: Negotiating Economic Partnership Agreements.' Journal of European Integration 30(3): 363-380. 
Elgström, O. and M. Smith. 2006. The European Union's Roles in International Politics. Concepts and Analysis. London and New York: Routledge.

Eriksen. E. O. 2016. 'Three Conceptions of Global Political Justice'. GLOBUS Research Papers, No. 1/2016. Oslo: ARENA.

Eriksen, E.O. and J. Weigård. 2003. Understanding Habermas: Communicative Action and Deliberative Democracy. London and New York: Continuum.

Fuchs, A., P. Nunnenkamp, and H. Öhler. 2015. 'Why Donors of Foreign Aid Do Not Coordinate: The role of competition for export markets and political support.' The World Economy 38(2): 255-85.

Furness, M. and S. Gänzle. 2017. 'The Security-Development Nexus in European Union Foreign Relations after Lisbon: Policy Coherence at Last?' Development Policy Review, 35(4): 475-492.

Habermas, J. 1993. Justification and Application: Remarks on Discourse Ethics. Cambridge: The MIT Press.

Hill, C. and M. Smith. 2005. International Relations and the European Union. Oxford: Oxford University Press.

Hofferberth, M. and C. Weber. 2015. 'Lost In Translation: A Critique of Constructivist Norm Research.' Journal of International Relations and Development 18(1): 75-103.

Holsti, K. J. 1970. 'National Role Conceptions in the Study of Foreign Policy.' International Studies Quarterly 14: 233-309.

Horký, O. 2012. 'What Coherence Between Foreign and Development Policy?' In The European Union and Global Development: An 'Enlightened Superpower' in the Making? edited by S. Gänzle, S. Grimm and D. Makhan. Basingstoke: Palgrave Macmillan.

Lumsdaine, D. H. 1993. Moral Vision in International Politics: The Foreign Aid Regime 1949-1989. Princeton NJ: Princeton University Press.

March, J. G. and J. P. Olsen. 2009. 'The Logic of Appropriateness.' In The Oxford Handbook of Public Policy, edited by R. Goodin, R. Moran, and M. Rein. Oxford: Oxford University Press.

Olsen, G. R. 2013. 'The European Union's Africa Policy: The Result of Nordicization or Europeanisation?' Journal of European Integration 35(4): 409-424.

Orbie, J. 2012. 'The EU's Role in Development: A Full-Fledged Development Actor or Eclipsed by Superpower Temptations?' In The European Union and Global Development, edited by S. Gänzle, S. Grimm, and D. Makhan. Basingstoke: Palgrave Macmillan.

Orbie, J. and M. Carbone. 2016. 'The Europanisation of Development Policy.' European Politics and Society 17(1): 1-11.

Orbie, J. and S. Lightfoot. 2017. 'Development. Shallow Europeanisation?' In Foreign Policies of EU Member States. Continuity and Europeanisation, edited by A. Hadfield, I. Manners and R. Whitman. London and New York: Routledge.

Puetter, U. and A. Wiener. 2007. 'Accomodating Normative Divergence in European Foreign Policy Co-ordination: The Example of the Iraq Crisis.' Journal of Common Market Studies 45(5): 1063-1086.

Risse, T. 2000. 'Let's Argue: Communicative Action in World Politics.' International Organisation 54(1): 1-39.

Sjursen, H. 2002. 'Why Expand? The Question of Legitimacy and Justification in the EU's Enlargement Policy.' Journal of Common Market Studies 40(3): 491-513.

Smith, M. 2013. 'Foreign Policy and Development in the Post-Lisbon European Union.' Cambridge Review of International Affairs 26(3): 519-535. 
Smith, M. 2016. 'Conclusions: Europeanisation, Globalisation or (Re)nationalisation? Revisiting Development Policy of the European Union.' European Politics and Society 17(1): 136-141.

Stokke, O. 1989. Western Middle Powers and Global Poverty. Uppsala: Scandinavian Institute for African Affairs.

Van Kersbergen, K. and B. Verbeek. 2007. 'The Politics of International Norms: Subsidiarity and the Imperfect Competence Regime of the European Union.' European Journal of International Relations 13(2): 217-238.

Versluys, H. 2008. 'Depoliticising and Europeanising Humanitarian Aid: Success or Failure?' Perspectives on European Politics and Society 9(2): 208-224.

Weber, M. 1978. Economy and Society: An Outline of Interpretive Sociology. Berkeley, CA: University of California Press.

Wiener, A. 2008. The Invisible Constitution of Politics: Contested Norms and International Encounters. Cambridge: Cambridge University Press.

Yin, R. 2014. Case Study Research: Design and Methods. Thousand Oaks: Sage.

\section{Official Documents}

Council of Ministers. 2007. EU Code of Conduct on Complementarity and Division of Labour in Development Policy, Council document No. 9558/07, 15 May, Brussels: Council of the European Union. Accessed June 2017. http://register.consilium.europa.eu/doc/srv?l=EN\&f=ST\%209558\%202007\%20INIT

European Commission. 2007. Communication from the Commission to the Council and the European Parliament. EU Code of Conduct on Division of Labour in Development Policy, COM(2007)72 Final, 28 February, Brussels: Commission of the European Communities. Accessed June 2017.

https://ec.europa.eu/europeaid/sites/devco/files/communication-labour-developmentpolicy-code-of-conduct-com200872-20070228_en.pdf

FOI DK. 2007a. Notat Hermed til specialudvalg kommenteret dagsorden Monterrey + Division of Labour, 1 July, Copenhagen: Danida.

FOI DK. 2007b. Utviklingsministerens samtale med sin tyske kollega - EU Dagsordenen, 19 February, Copenhagen: Danida.

FOI DK. 2007c. EU Code of Conduct for Complementarity and Division of Labour, 5 March, Copenhagen: Danida.

FOI DK. 2007d. Instruktion: Møde I COREPER II d. 10.05.2007 - Code of Conduct on Complementarity and Division of Labour, 9 May, Copenhagen, Danida.

FOI DK. 2007e. Letter from Ulla Tørnæs to Ms. Wieczorek-Zeul, 20 March, Copenhagen: Danida.

FOI UK. 2007a. DFID Ministerial submission dated 27 April 2007 about how to ensure that the code of conduct allows DFID the flexibility to respond to developing countries' needs, 27 April, London: DFID.

FOI UK. 2007b. Technical Seminar on EU Division of Labour, Brussels 30-31 January 2007, 1 February, London: DFID.

FOI UK. 2007c. Explanatory memorandum on a European Community Document. Submitted by the Department for International Development, 19 April, London: DFID.

House of Commons. 2007. EU Development Policy, Debate in the European Standing Committee, 8 May, London: House of Commons.

Utrikesdepartementet. 2007. EU:s uppförandekod för arbetsfördelning på området utvecklingspolitik, Utrikesdepartementet 14 May, Stockholm: Utrikesdepartementet.

\section{Interviews}

1. COM-1, Official, DG Devco, 11/8/16 
2. COM-2, Official, DG Devco, 11/8/16

3. COM-3, Official, DG Devco, 31/8/16

4. COM-4, Manager, DG Devco, 1/9/16

5. COM-5, Official, DG Devco, 13/10/16

6. COU-1, Official, Council Secretariat, 31/8/16

7. MS-1, Member state official, $18 / 8 / 16$

8. MS-2, Member state official, $30 / 8 / 16$

9. MS-3, Member state official, 2/9/16

10. MS-4, Member state official, 12/9/16

11. MS-5, Member state official, 12/9/16

12. MS-6, Member state official, 14/9/16

13. MS-7, Member state official, 16/9/16

14. MS-8, Member state official, 21/9/16

15. MS-9, Member state official, 10/10/16 